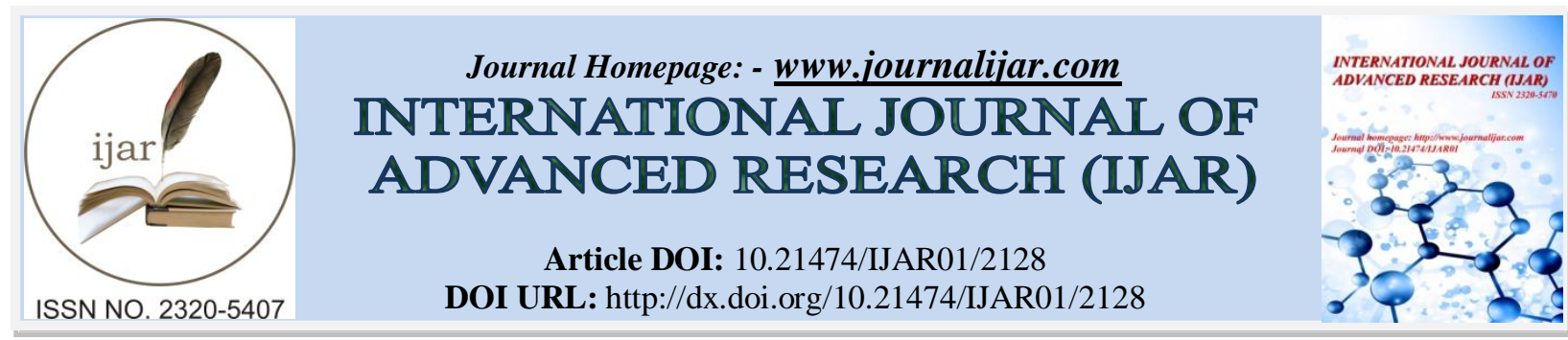

RESEARCH ARTICLE

\title{
SURVEY AND POPULATION DYNAMIC OF TERRESTRIAL GASTROPODS INFESTING CERTAIN CROPS AT SHARKIA GOVERNORATE, EGYPT.
}

\author{
Abou Senna. F. M. ${ }^{1}$, Almaraghy. A. H. A. ${ }^{1}$, Ismail. Sh. A. A. ${ }^{2}$ and Abed. M. ${ }^{2}$ \\ 1. Zoology and Entomology Department, Faculty of Science, Al-Azhar University, Cairo, Egypt. \\ 2. Plant Protection Research Institute, Agricultural Research Center, Dokki, Giza, Egypt.
}

\section{Manuscript Info}

Manuscript History

Received: 25 September 2016

Final Accepted: 27 October 2016

Published: November 2016

Key words:-

Survey, Terrestrial gastropods, Sharkia

Governorate, Egypt.

\section{Abstract}

This study was carried out on certain places at Sharkia Governorate, Egypt to survey the most common terrestrial gastropods infesting vegetable and field crops. Results revealed that most crops highly infested with Monacha cartusiana snails, while Succinea putris and Deroceras laeve had moderately to low infestation. As in the case of Monacha cantiana, it was recorded for the first time on Sharkia Governorate. Regarding population dynamics Egyptian clover harbored the highest numbers of snails, followed by wheat and sugar beet during February, March and April. Inconstant relationship were found between population dynamics and both temperature and relative humidity.

Copy Right, IJAR, 2016,. All rights reserved.

\section{Introduction:-}

Molluscs are the second huge phylum of the animal kingdom, forming a major part of the world fauna (Lush, 2007). So, they are considered one of the most successful phyla among the animal kingdom. Gastropods are the most successful molluscs which have invaded land (Smith and Kershaw, 1979). The $20^{\text {th }}$ century witnessed the emergence of gastropods as important crop pests in temperate and tropical regions, the increased pest status has been associated with cultivation of new crops, intensification of agricultural production systems, and the spread through human trade and travel of species adapted to these modified environments (Barker, 2002). Among gastropods, are land snails belonging to subclass, Pulmonata which is one of the most numerous with almost 35,000 described species of the world (Solem, 1984). In Egypt, land molluscs are introduced as new pests in agricultural crops, it caused great damage to vegetable and field crops, orchards and other plants (Kassab and Daoud, 1964 and Asran, 1994). This study aimed to surveying the most important endemic gastropods and population dynamic for the most common species infesting certain field crops at Sharkia Governorate, Egypt.

\section{Materials And Methods:-}

Survey of terrestrial gastropods infesting different crops at Sharkia Governorate:-

A survey study was carried out at three districts (Hehia, El-Ibrahimia and Deiarb Negm) in Sharkia Governorate, Egypt during the period from October 2013 till September 2015. At each district, three villages were randomly chosen. These localities were Hehia: (Hehia El-Balad, Mahdia and Manzel-Hayan), El-Ibrahimia: (El-Hebsh, Kafr El-Shorafa and Mubasher) and Deiarb-Negm: (Ekrash, El-Hawaber and El-Mugafaf). Survey was undertaken on many host plant species including filed crops as Egyptian clover, (Trifolium alexandrinum); maize, (Zae mays); wheat, (Triticum aestivum); broad bean, (Vicia faba): sugar beet, (Beta vulgaris); barley, (Hordeum vulgare) and kidney bean, (Phaseolus vulgaris) and vegetable crops i.e. cabbage, (Brassica oleracea); onion, (Allium cepa);

Corresponding Author:- Abou Senna. F. M.

Address:- Zoology and Entomology Department, Faculty of Science, Al-Azhar University, Cairo, Egypt. 
lettuce, (Lactuca sativa); egg plant, (Solanum melongena); tomato, (Solanum lycopersicum); cucumber, (Cucumis sativus); garlic, (Allium sativum); okra, (Abelmoschus esculentus); dill, (Anethum graveolens) and parsley, (Petroselinum crispum). Samples were taken from each field crop by using the quadrate sample size 50x50cm (Staikou et al., 1990). Snails from each host plant in the different host plant were collected and transfer in plastic box to laboratory for identification using key given by (Godan, 1983).

\section{Population dynamics of Monacha cartusiana on certain field crops:-}

The seasonal population dynamics of $M$. cartusiana infesting certain field crops were studied at Mubasher village El-Ibrahimia district during two successive growing seasons (2014/2015 and 2015/2016). Three field crops Egyptian clover, wheat and sugar beet were chosen for this study. An area of about one feddan was selected for each crop. Five replicates of quadrate sample size $(50 \times 50 \mathrm{~cm})$ were examined biweekly intervals during the growing season of each crop (Staikou et al., 1988). Examination was undertaken during early morning in absence of sunshine. All snails found on plants or on soil surface in the quadrate were counted and left in their initial places (Baker, 1988). Data concerning temperature and relative humidity during the period of study were obtained from the Metrological Station of Zagazig. Obtained data were subjected to statistical analysis as correlation coefficient between snails population and each of temperature and relative humidity according to (Costat, 2005).

\section{Results:-}

Survey studies of terrestrial gastropods in certain districts at Sharkia Governorate:-

An extensive survey was carried out on terrestrial molluscs infesting different crops at 9 villages belonging to three districts at Sharkia Governorate. Results present in Table (1) revealed that three species of herbivorous land snails were found on different host plants. Moreover terrestrial slug belonging to different families of order: stylommatophora. These families were: Hygromiidae (Monacha cartusiana and Monacha cantiana), Succineidae (Succinea putris) and family: Agriolimacidae (Deroceras laeve) Fig., (1). The identified species varied in their incidence and level of infestation according to the locality and the host type. It obvious that M. cartusiana snail has the upper hand on terrestrial molluscs incidence compared with the other species since it was recorded in all surveyed localities. Moreover, the majority of the examined plants were liable to be infested by this snail followed by $S$. putris, M. cantiana while $D$. laeve was the lowest one observed on the host plant. Generally, the listed hosts can be classified into three categories according to the degree of infestation. These categories were heavy, moderate and light infestation. The majority of examined crops were found with heavy infestation with $M$. cartusiana especially Egyptian clover, wheat, lettuce, cabbage. Broad bean, egg plant, onion, cucumber and kidney bean were detected with moderate infestation. On the other hand, barley, maize, garlic, okra, sugar beet, dill, tomato and parsley were detected with light infestation. In respect to S. putris, M. cantiana and D. laeve they recorded for the first time on Egyptian clover and wheat at Mubasher village (El-Ibrahimia district) with moderate to light infestation. 


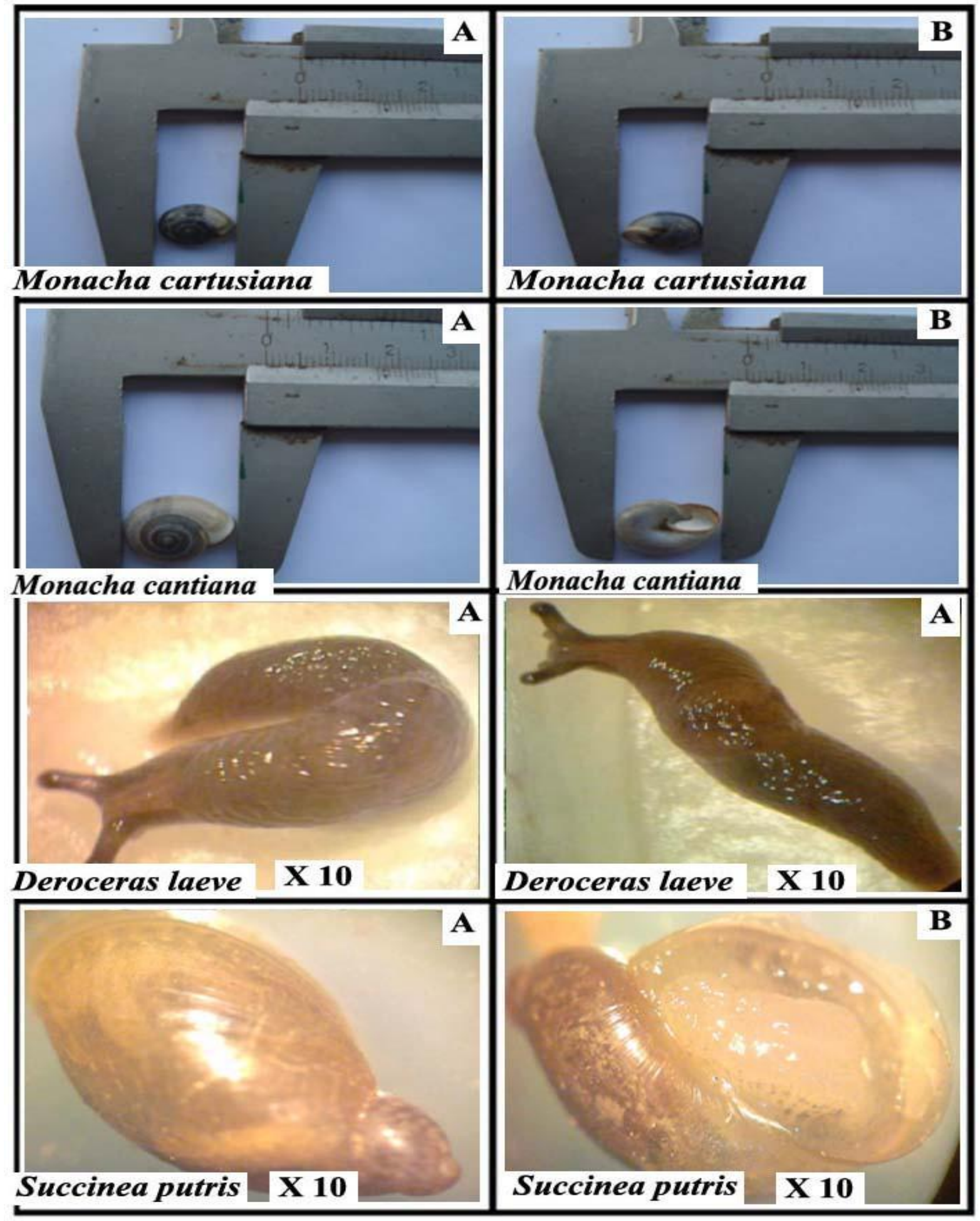

Fig 1:- Terrestrial gastropod occurred on Sharkia Governorate. Note (A) dorsal view, (B) ventral view. 
Table 1:- Survey of terrestrial gastropods and level of infestation on different corps at certain districts at Sharkia Governorate.

\begin{tabular}{|c|c|c|c|}
\hline District & Localities & $\begin{array}{l}\text { Gastropod } \\
\text { species }\end{array}$ & Host plant \\
\hline \multirow{4}{*}{ Hehia } & \multirow[t]{2}{*}{$\begin{array}{l}\text { Hehia } \quad \text { El- } \\
\text { Balad }\end{array}$} & $\begin{array}{l}\text { M. } \\
\text { cartusiana }\end{array}$ & $\begin{array}{l}\text { Egyptian clover(+++), Wheat(+++), Broad bean(++), Barley(+), } \\
\text { Maize }(+) \text {, Cabbage }(+++) \text { Lettuce }(+++) \text {, Egg plant }(++) \text {, } \\
\text { Onion(++), Cucumber(++), Garlic }(+), \text { Okra(+), Tomato }(+)\end{array}$ \\
\hline & & S. putris & Egyptian clover $(+)$ \\
\hline & Mahdia & $\begin{array}{l}\text { M. } \\
\text { cartusiana } \\
\end{array}$ & $\begin{array}{l}\text { Egyptian clover }(+++) \text {, Wheat(++), Lettuce(+++), Egg plant(+), } \\
\text { Onion }(+), \text { Cabbage }(+++), \text { Dill }(+), \text { Parsley }(+)\end{array}$ \\
\hline & $\begin{array}{l}\text { Manzel- } \\
\text { Hayan }\end{array}$ & $\begin{array}{l}\text { M. } \\
\text { cartusiana }\end{array}$ & $\begin{array}{l}\text { Egyptian clover }(+++) \text {, Wheat }(++), \text { Onion }(+), \text { Cabbage }(+++) \text {, } \\
\text { Dill }(+), \text { Parsley }(+)\end{array}$ \\
\hline \multirow{6}{*}{ El-Ibrahimia } & El-Hebsh & $\begin{array}{l}\text { M. } \\
\text { cartusiana }\end{array}$ & Egyptian clover $(++)$, Wheat $(+)$, Onion(+), Cabbage $(+++)$ \\
\hline & $\begin{array}{ll}\text { Kafr } & \text { El- } \\
\text { Shurafa } & \end{array}$ & $\begin{array}{l}\text { M. } \\
\text { cartusiana }\end{array}$ & $\begin{array}{llll}\text { Egyptian clover } & (+++), & \text { Wheat }(+++), & \text { Cabbage }(+++), \\
\text { Lettuce }(+++)\end{array}$ \\
\hline & \multirow{4}{*}{ Mubasher } & $\begin{array}{l}\text { M. } \\
\text { cartusiana }\end{array}$ & $\begin{array}{l}\text { Egyptian clover }(+++) \text {, Wheat(+++), Broad bean(+), Onion(+), } \\
\text { Garlic(+), Lettuce(+), Sugar beet }(+) \text {, Kidney bean }(++)\end{array}$ \\
\hline & & S. putris & Egyptian clover $(++)$, Wheat $(+)$ \\
\hline & & D. laeve & Wheat $(+)$ \\
\hline & & M. cantiana & Egyptian clover (++), Wheat(+) \\
\hline \multirow{3}{*}{ Deiarb-Negm } & Ekrash & $\begin{array}{l}\text { M. } \\
\text { cartusiana }\end{array}$ & Egyptian clover $(+++)$, Wheat(++), Egg plant(+) \\
\hline & El-Hawaber & $\begin{array}{l}\text { M. } \\
\text { cartusiana }\end{array}$ & Egyptian clover $(+++)$, Wheat(+++), Onion(+) \\
\hline & El-Mugafaf & $\begin{array}{l}\text { M. } \\
\text { cartusiana } \\
\end{array}$ & Egyptian clover (++), Wheat(+), Lettuce(+), Okra(+) \\
\hline
\end{tabular}

$(+)=$ low infestation (less than 15 snails $/ 0.25 \mathrm{~m}^{2}$ ).

$(++)=$ Moderate infestation (between $16-30$ snails $/ 0.25 \mathrm{~m}^{2}$ ).

$(+++)=$ heavy infestation (more than 30 snail $/ 0.25 \mathrm{~m}^{2}$ ).

\section{Seasonal population dynamics of $M$. cartusiana on certain field crops at Sharkia Governorate:-}

Survey studies showed that the glassy clover snail $M$. cartusiana was the predominant species with a relatively high numbers on major economic crops. Therefore, population dynamics of such snail was studied on Egyptian clover, wheat and sugar beet in Mubasher village, El-Ibrahimia district, Sharkia Governorate during the two successive growing seasons 2014/2015 and 2015/2016. Data in Table (2) and Fig., (3\&4\&5) showed that the initial infestation of $M$. cartusiana was appeared in the beginning of November on Egyptian clover with a relatively low population densities of $(2.8 \& 2.2)$ snails per quadrate size of $50 \times 50 \mathrm{~cm}$ in the growing season 2014/2015 and 2015/2016, respectively While on sugar beet the initial infestation was appeared in the beginning of December with a relatively low population densities of $(0.6 \& 0.4)$ snails per quadrate sample size of $50 \times 50 \mathrm{~cm}$ in the growing season 2014/2015 and 2015/2016, respectively. In respect to Wheat the initial infestation was appeared in the mid of February with a relatively low population densities of $(8.6 \& 13.4)$ snails per quadrate sample size of $50 \times 50 \mathrm{~cm}$ in the growing season 2014/2015 and 2015/2016, respectively. Regarding the behavior of M. cartusiana population after the initial infestation, it is cleared that the number of snails were slightly increased to reach its peck (89.6, 58.4\& 30.2, 29.4) at the mid of March for two successive growing season 2014/2015 and 2015/2016 for Egyptian clover and wheat, respectively. The number of snail per quadrate sample size of $50 \times 50 \mathrm{~cm}$ at the end of growing season 2014/2015 and 2015/2016 for Egyptian clover, wheat and sugar beet were (19\& 10.4), (21.4\& 18.6) and (11.6\& 9.8), respectively.

In general, it noticed that, Egyptian clover harbored the highest number of snail per quadrate sample size 50x50 in which general mean record (25.64 \& 23.49) for two successive season 2014/2015 and 2015/2016 followed by wheat ( $7.94 \& 7.88)$ while sugar beet is the lowest one which gave $(3.28 \& 2.78)$. 
Table 2:- Population dynamic of $M$. carusiana in Mubasher village, El-Ibrahimia district, Sharkia Governorate during the two growing seasons 2014/2015 and 2015/2016.

\begin{tabular}{|c|c|c|c|c|c|c|c|c|c|c|}
\hline \multirow{3}{*}{ Date of inspection } & \multicolumn{6}{|c|}{ Avarege number of snail sample/ $0.25 \mathrm{~m}^{2}$} & \multirow{2}{*}{\multicolumn{2}{|c|}{ Temperature $\left({ }^{\circ} \mathrm{C}\right)$}} & \multirow{2}{*}{\multicolumn{2}{|c|}{ R.H. \% }} \\
\hline & \multicolumn{2}{|c|}{ Egyptian clover } & \multicolumn{2}{|c|}{ Wheat } & \multicolumn{2}{|c|}{ Sugar beet } & & & & \\
\hline & $\begin{array}{l}2014 / \\
2015 \\
\end{array}$ & $\begin{array}{l}2015 / \\
2016\end{array}$ & $\begin{array}{l}2014 / \\
2015\end{array}$ & $\begin{array}{l}2015 / \\
2016\end{array}$ & $\begin{array}{l}2014 / \\
2015 \\
\end{array}$ & $\begin{array}{l}2015 / \\
2016\end{array}$ & $\begin{array}{l}2014 / \\
2015 \\
\end{array}$ & $\begin{array}{l}2015 / \\
2016\end{array}$ & $\begin{array}{l}2014 / \\
2015 \\
\end{array}$ & $\begin{array}{l}2015 / \\
2016\end{array}$ \\
\hline 1 Sep. & - & - & - & - & 0 & 0 & 30 & 27.75 & 52.63 & 48.59 \\
\hline $16 \mathrm{Sep}$. & - & - & - & - & 0 & 0 & 28.8 & 29.8 & 48.3 & 54.73 \\
\hline 1 Oct. & - & - & - & - & 0 & 0 & 28.03 & 30.76 & 47.33 & 41.57 \\
\hline 16 Oct. & 0 & 0 & - & - & 0 & 0 & 24.4 & 26.47 & 51.2 & 53.33 \\
\hline 1 Nov. & 2.8 & 2.2 & - & - & 0 & 0 & 23.59 & 23 & 48.59 & 51.38 \\
\hline 16 Nov. & 1 & 0.4 & 0 & 0 & 0 & 0 & 21.36 & 20.97 & 50.73 & 64.7 \\
\hline 1 Dec. & 3.2 & 0.8 & 0 & 0 & 0.6 & 0.4 & 18.16 & 20.9 & 60.26 & 53.5 \\
\hline 16 Dec. & 5.6 & 1.2 & 0 & 0 & 2.6 & 2.4 & 18.6 & 15.97 & 53.47 & 58.77 \\
\hline 1 Jun. & 4.8 & 7 & 0 & 0 & 5 & 4.8 & 15.78 & 14.31 & 53.88 & 54.86 \\
\hline 16 Jun. & 10.4 & 9 & 0 & 0 & 7.2 & 5.2 & 11.83 & 15.2 & 48.93 & 49.3 \\
\hline 1 Feb. & 17 & 16.6 & 0 & 0 & 12.4 & 10.8 & 15.68 & 11.13 & 46.88 & 53 \\
\hline $16 \mathrm{Feb}$. & 32.2 & 42.4 & 8.6 & 13.4 & 11.6 & 9.8 & 15.17 & 16.2 & 41.6 & 52.73 \\
\hline 1 Mar. & 34.6 & 55.2 & 19.2 & 17.4 & - & - & 14.19 & 24.71 & 55.92 & 50 \\
\hline 16 Mar. & 89.6 & 58.4 & 30.2 & 29.4 & - & - & 18.1 & 21.57 & 56.07 & 45.3 \\
\hline 1 Apr. & 60.4 & 44.8 & 21.4 & 18.6 & - & - & 18.84 & 19.16 & 49.44 & 43.41 \\
\hline 16 Apr. & 52.2 & 56.8 & - & - & - & - & 19.37 & 25.3 & 48.7 & 42.73 \\
\hline 1 May & 51.8 & 47.2 & - & - & - & - & 22.47 & 25.53 & 38.53 & 40.17 \\
\hline 16 May & 19 & 10.4 & - & - & - & - & 27.47 & 27.87 & 51.3 & 43.1 \\
\hline Total & 384.6 & 352.4 & 79.4 & 78.8 & 39.4 & 33.4 & & & & \\
\hline General mean & 25.64 & 23.49 & 7.94 & 7.88 & 3.28 & 2.78 & & & & \\
\hline
\end{tabular}

The correlations between some climatic factor i.e. temperature or relative humidity and population density of $M$. cartusiana during the two successive growing seasons were subjected to statistical analysis. Data presented in Table (3) and Fig., (2) revealed that temperature and relative humidity showed a variable effect on population density of M. cartusiana. Since correlation coefficient values differed from one host to another in the two seasons of the experiment. For instance on wheat and Egyptian clover temperature showed insignificant positive effect on number of $M$. cartusiana during growing seasons $2015 / 2016$. On the other hand insignificant negative correlation was found on Egyptian clover during 2014/2015 and on sugar beet during 2015/2016. In contrast highly significant negative effect was observed on sugar beet during season 2014/2015. Concerning the effect of relative humidity on population density of $M$. cartusiana, it was noticed that the obtained results were not constant for sample. Insignificant negative correlation was observed on Egyptian clover during growing season 2014/2015 and growing season 2015/2016 for sugar beet. While highly significant negative correlation was noticed on Egyptian clover during growing season 2015/2016 and during 2014/2015 for sugar beet. In respect to wheat insignificant positive correlation was noticed during growing season 2014/2015 and significant negative correlation was observed during growing season 2015/2016. Generally, there is no definite correlation between temperature or relative humidity and population dynamic of $M$. cartusiana during the two successive seasons.

Table 3:- Correlation between temperature, relative humidity and population density of Monacha cartusiana on different crops at Sharkia Governorate.

\begin{tabular}{|l|l|l|l|l|}
\hline \multirow{2}{*}{ Host plant } & \multicolumn{3}{|l|}{ Temperature $^{\circ} \mathrm{C}$} & Relative humidity \% \\
\cline { 2 - 5 } & $2014 / 2015$ & $2015 / 2016$ & $2014 / 2015$ & $2015 / 2016$ \\
\hline Egyptian clover & $-0.097 \mathrm{~ns}$ & $0.222 \mathrm{~ns}$ & $-0.158 \mathrm{~ns}$ & $-0.653^{* *}$ \\
\hline Wheat & $0.074 \mathrm{~ns}$ & $0.540 \mathrm{~ns}$ & $0.138 \mathrm{~ns}$ & $-0.699 *$ \\
\hline Sugar beet & $-0.746 * *$ & $-0.792 \mathrm{~ns}$ & $-0.511 * *$ & $-0.001 \mathrm{~ns}$ \\
\hline
\end{tabular}

$\mathrm{ns}=$ not significant $*=$ significant $\quad * *=$ highly significant 


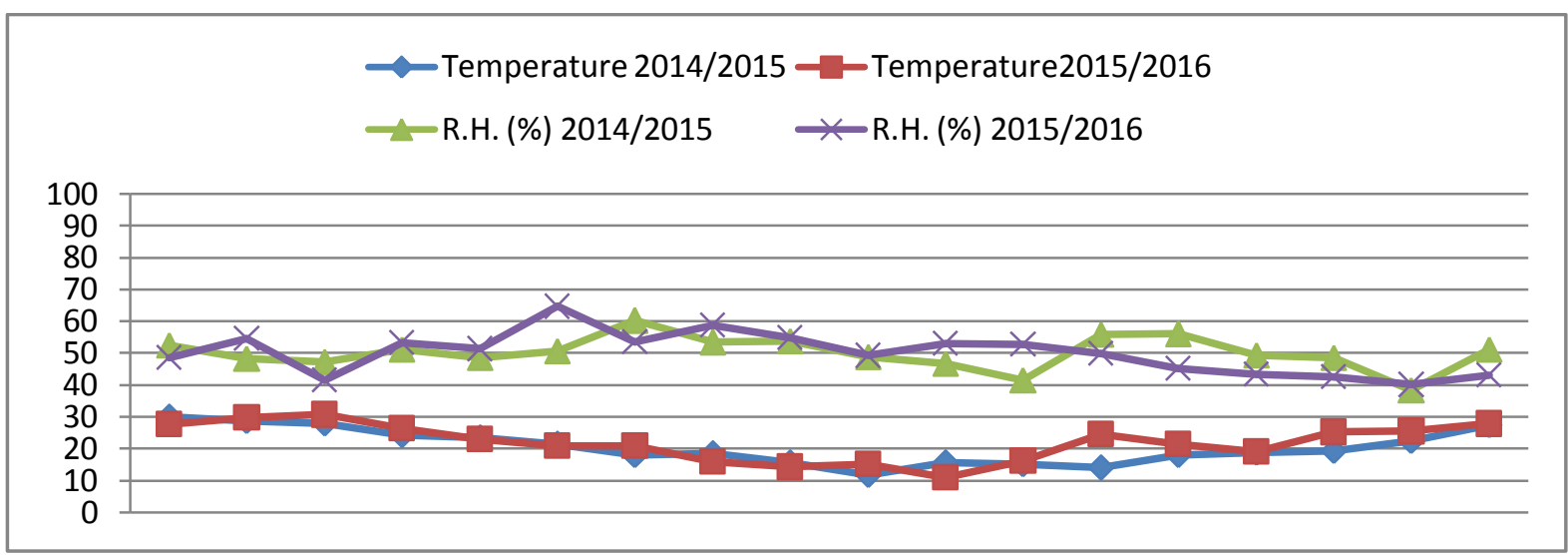

Fig 2:- Temperature and relative humidity during two successive seasons 2014/2015 and 2015/2016.

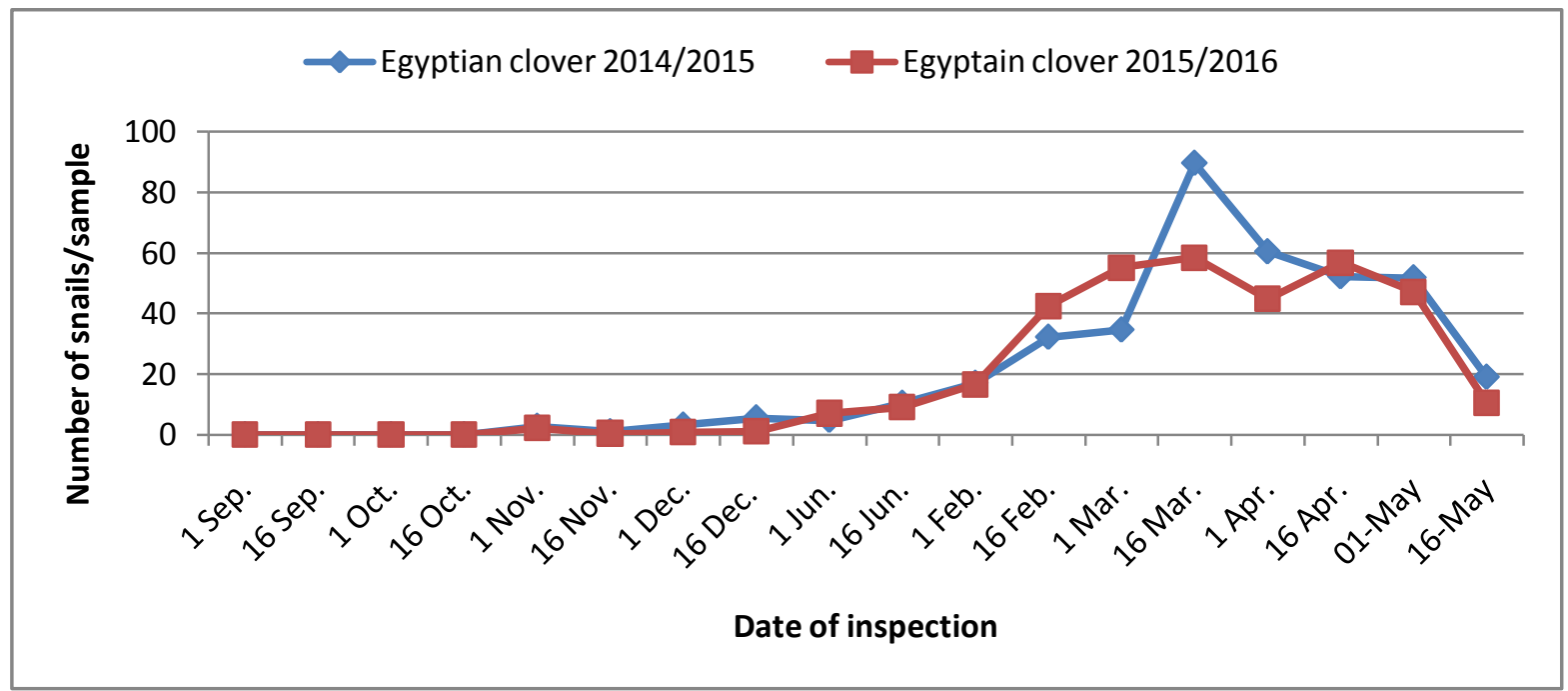

Fig 3:- Population dynamics of $M$. cartusiana snail infesting Egyptian clover in Mubasher village during two successive season 2014/2015 and 2015/2016.

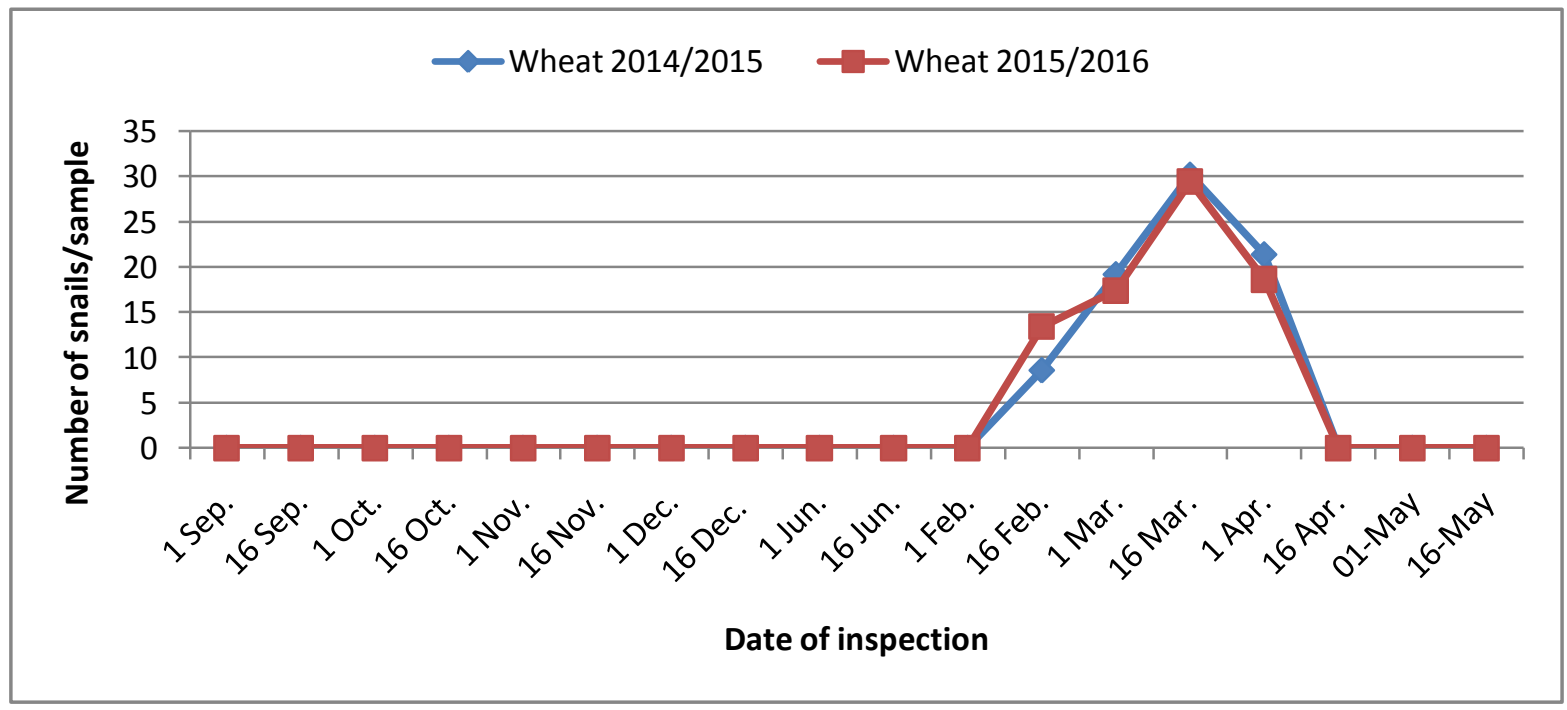

Fig 4:- Population dynamics of M. cartusiana snail infesting wheat in Mubasher village during two successive season 2014/2015 and 2015/2016. 


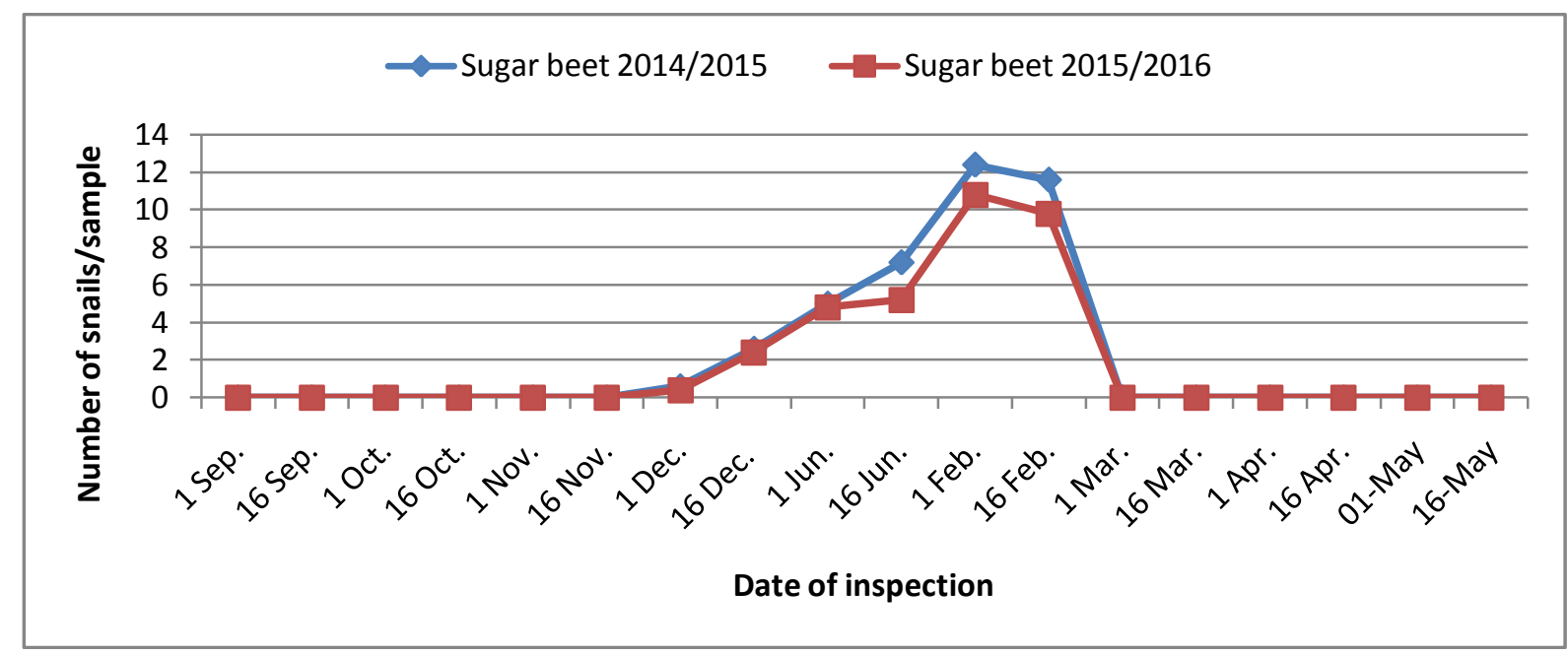

Fig 5:- Population dynamics of $M$. cartusiana snail infesting sugar beet in Mubasher village during two successive season 2014/2015 and 2015/2016.

\section{Discussion:-}

Results of the present study revealed that the land snail $M$. cartusiana snail occupy the first on incidences and level of infestation followed by $S$. putris while D. laeve was found on some locality at Sharkia Govenorate. While, $M$. cantiana recorded for the first time at Sharkia Governorate. Discussing the foregoing results, it is well know that land snails and slugs were recorded as serious pests to agricultural crops in different places in Egypt. The terrestrial snails were found at different Governorates attacking many economic crops. For instances: at Sharkia Governorate, Arafa, (1997) found that, M. cartusiana infested hosts with few, moderate and high numbers in Meniet El-Kamh district. Mahrous et al., (2002) detected five species of land snails in different localities of Sharkia Governorate. There were 12 districts containing 44 localities infested with land snails, M. cartusiana, Helicella vestalis, Cochlicella acuta, Eobania vermiculata and Succinea sp. Shetaia, (2005) surveyed the terrestrial molluscs infesting different crops at 14 localities representing 7 districts of Sharkia Governorate. Five herbivorous land snail species were found on different host plants. These species were M. cartusiana, $H$. vestalis, E. vermiculata, C. acuta and S. putris. Ghareb, (2007) cleared that, the land snail M. cartusiana was the only snail which found in all in 12 villages at Meniet El-Khamh district, Sharkia Governorate, while, S. putris land snail was appeared only one time as individual snail in El-Godaida village. Lokma, (2007) revealed that the glassy clover snail, M. cartusiana infested the examined crops in all inspected localities of Sharkia Governorate, except wheat and broad been in Serag ELDeen (Belbies district) and wheat as well as broad bean in Kafr-Sakr El-Balad and Teliga (Kafr-Sakr district), respectively, while the conical snail C. acuta was found in El-Katiba village (Belbies district). The slugs Deroceras reticulatum and $D$. laeve were recorded for the first time on Egyptian clover in Meniet El-Kamh and Zagazig districts. Shetaia et al., (2009) reported that the glassy clover snail M. cartusiana and the amber snail, S. putris were found at Awlad-Sakr and Abo-Kapeer district, Sharkia Governorate. M. cartusiana snail was found with higher density than $S$. putris. The majority of examined crops were found with heavy infestation with $M$. cartusiana snail while $S$. putris were recorded with moderate or light infestation in the examined localities. Ismail et al., (2011) revealed that, $M$. cartusiana and S. putris snails were found at Hehia and Meniet El- Kamh while M. cartusiana was found with higher density than $S$. putris on agricultural crops and weeds. The majority of the examined crops were found with heavy infestation with $M$. cartusiana while infestation with $S$. putris was found light of moderate. Rady et al., (2014) revealed that five species were found infesting different crops in Ismailia and Sharkia Governorates. These species were $M$. cartusiana, $C$. acuta, S. putris, D. laeve and D. reticulatum. The last species was recorded for the first time in Ismailia Governorate.

Regarding, seasonal population dynamics of M. cartusiana snail on certain field crops at Sharkia Governorate. The present study revealed that Egyptian clover harbored the highest numbers of $M$. cartusiana followed by wheat while sugar beet showed the lowest number. Population density values of $M$. cartusiana on the tested crops were higher than in the first growing season 2014/ 2015 compared to those counted in the later growing season of 2015/2016. In Egyptian clover and wheat crops the population density of M. cartusiana obviously increased during (February, 
March and April) months as compared to the other months. In respect to sugar beet the population density was high in January and February months compared with the other months.

Obtained results of population dynamics on different crops at Mubasher village were very similar to results reported by many authors. Ismail, (1997) revealed that the population density of $M$. cartusiana on field and vegetable crops was obviously increased during spring months as compared to the population density during winter and autumn months in certain localities of Sharkia Governorate, while the infestation did not appear during summer months. Moreover, Egyptian clover harbored the highest numbers of $M$. cartusiana followed by cabbage and wheat. On the other hand, there is no definite correlation between temperature or relative humidity and population density of $M$. cartusiana on the tested crops during the two successive growing seasons of the study. Hegab et al., (1999) found that Egyptian clover harbored the highest numbers of M. cartusiana followed by wheat, while broad bean showed the lowest numbers. Mahrous $\boldsymbol{e t}$ al., (2002) reported that the population density of M. cartusiana was obviously increased during spring months (March, April, and May) as compared to low or moderate values during winter and autumn months at Sharkia Governorate. Lokma, (2007) found that population density of this snail was obviously increased during spring months as compared to low or moderate values during autumn and winter months. Egyptian clover harbored the highest numbers followed by wheat. Ismail et al., (2011) showed that population dynamics of M. cartusiana at Abo-Kapeer district, Sharkia Governorate was recorded with high density during spring months (March, April and May) as compared with winter or fall months. Awad, (2013) revealed that, the population density of these land snails were observed on the soil, stems and leaves of tested crops. The population density of all observed land snails was heavier on Egyptian clover followed by wheat and sugar beet, also recoded highest numbers through spring season followed by autumn and winter.

These results disagree with Shetaia, (2005) who found that at Kafr-Sakr district, Sharkia Governorate the highest population densities of M. carusiana on wheat was recorded during April. On the other hand, Egyptian clover gained the highest values of population density in May, during the two successive growing seasons of 1999/2000 and 2000/2001.

\section{References:-}

1. Arafa, A. A. I. (1997). Studies on some land molluscs at Sharkia Governorate. M.Sc. Thesis, Fac. Agric., AlAzhar Univ. 137 pp.

2. Asran, Fawkyia. D. A. (1994). Studies on harmful terrestrial snails and their management on Egyptian agriculture lands. M.Sc. Thesis, Instit. Environ. Stud. \& Res., Ain Shams Univ., Cairo, 125 pp.

3. Awad, M. H. M. (2013). Logical control and population density studies on land snails in South district of Port Saied, Portsaied Governorate. Egypt. Acad. J. Biolo. Sci., 5 (2): 47- 63.

4. Baker, G. H. (1988). The life history, population dynamics and polymorphism of Cernuella virgata (Mollusca: Helicidae). Aust. J. Zool., (36):497-512.

5. Barker, G. M. (2002). Molluscs as crop pests. CABI Publishing, Wallingford, UK, 468 pp.

6. Costat (2005) .Version 6.311, Copyright(c), CoHort Software, 798 Lighthouse Ave. PMB 320, Monterey, CA, 93940, USA.

7. Ghareb, Hend, SH. (2007). Studies on certain internal and external parasites infesting some land snails M.Sc. Thesis, Fac. Sci., Benha Univ., 147pp.

8. Godan, D. (1983). Pest slugs and snails, biology and control. Springer-Verlag Berlin, Heidelberg., 445 pp.

9. Hegab, A. M. I.; Ghamry E.M.; El-Massry, S. A. A. and Hassan, A. I. (1999). Ecological studies on certain land snails in some localities at Sharkia Governorate. Zagazig J. Agric. Res., 26 (3B): 787 - 795.

10. Ismail, Sh. A. A. (1997). Ecology, biology and control of certain terrestrial snails infesting some vegetable and field crops in Sharkia Governorate. Ph.D. Thesis, Fac. Agric., Zagazig Univ., 130 pp.

11. Ismail, Sh. A. A.; Shetaia, S. Z. S; Arafa, A. I. and Abd- EL- Atty, A. F. (2011). Incidence and seasonal fluctuation of certain land gastropod species associated with some crops and weeds at Sharkia Governorate .J. Plant Prot. and Path., Mansoura Univ., 2 (2):1103-1110.

12. Kassab, A. and Daoud, H. (1964). Notes on the biology and control of land snail of economic importance in the U.A.R. Agric. Res. Rev., 42: 77-98.

13. Lokma, M. H. E. (2007). Studies on some terrestrial gastropods injurious to field crops at Sharkia Governorate. M. Sc. Thesis, Fac. Agric, Zagazig Univ., 147pp.

14. Lush, A.L. (2007). Biology and ecology of the introduced snail Microxeromagna armillata in South Eastern Australia. Ph.D. Thesis, School of Agriculture, Food and Wine, Univ. Adelaide, Australia., 228 pp. 
15. Mahrous, M. E.; Ibrahim Mervat, H. and Abd El-Aal, E. M. (2002a). Occurance, population density and importance value of land snails infesting different crops in Sharkia Governarte, Egypt. Zagazig J. Agric. Res., 29 (2): $613-629$.

16. Shetaia, S. Z. (2005). Integrated control of land snail pests in the fields of Sharkia Governorate. Ph.D. Thesis, Fac. Agric., Al-Azhar Univ., 150 pp.

17. Shetaia, S. Z. S.; Ismail, Sh. A. A. and Abd El-Kader, Samah, M. (2009). Survey, population dynamics and importance value of certain land snail species infesting different crops in Sharkia Governorate. Egypt. Acad. J. Biolog. Sci., 1 (1): 37-43.

18. Smith, B. J. and Kershaw, R. C. (1979). Field guide to the non-marine molluscs of south eastern Australlia. Canberra: Australian National Univ., 283pp.

19. Solem, A. (1984). A world model of land snail diversity and abundance. In: Solem A., van Bruggen A. C. (Eds.). World-Wide Snails: Biogeographical Studies on Non-Marine Mollusca. Leiden., 6-22.

20. Staikou, A.; Lazaridou-Dimitriadou M. and Farmakis, N. (1988). Aspects of the life cycle, population dynamics, growth and secondary production of the edible snail Helix lucorum Linnaeus, 1958 (Gastropoda: Pulmonata) in Greece. J. Moll. Stud. 45: 139- 155.

21. Staikou, A.; Lazaridou-Dimitriadou M. and Pana, E. (1990). The life cycle, population dynamics, growth and secondary production of the snail Bradybaena fruticum (Gastropoda: Pulmonata) in Northern Greece. J. Moll. Stud., 56: 137- 146.

22. Rady, G. H.; Abd-ElGawad, A. A.; Ismail, SH. A. A. and Lokma, M. H. (2014). Ecology of some terrestrial molluscs in Sharkia and Ismailia Governorate. Egypt. J. Agric. Res., 92 (3): 907- 920. 